\title{
Analysis of Access to Clean Development Mechanism Landfill Projects through a Multi-Agent Model
}

\author{
Silvia Cruz and Sônia Paulino
}

\begin{abstract}
This paper analyzes Clean Development Mechanism (CDM) landfill projects, with emphasis on stakeholder access to the implementation and results from the projects developed in the Bandeirantes and São João landfills, both located in the city of São Paulo, Brazil. The analysis is based on a multi-agent model. It was concluded that, in the landfills studied, there is no effective information flow or coordination with the different community stakeholders whose participation is limited to public meetings held to discuss the allocation of revenues derived from the sale of carbon credits.
\end{abstract}

Index Terms-Clean development mechanism, multi-agent model, landfills, carbon credits.

\section{INTRODUCTION}

This paper analyzes Clean Development Mechanism (CDM) landfill projects, with emphasis on stakeholder access to the implementation and results from the projects developed in the Bandeirantes and São João landfills, both located in the city of São Paulo.

These landfills, from 1979 to 2007 received almost the entirety of the municipal solid waste collected in São Paulo, Brazil's most populous city, with around 11 million inhabitants, and Brazil's largest generator of municipal solid waste.

In 1997 the Kyoto Protocol (KP) [1] was established, from an agreement reached at the third Conference of the Parties of the United Nations Framework Convention on Climate Change (UNFCCC). This Protocol states that the countries included in Annex I, comprising the industrialized countries that in 1992 were OECD members, and countries with economies in transition, should reduce their emission levels of greenhouse gases (GHG) to targets that are mainly set below their 1990 levels, over the period 2008 to 2012.

To assist the countries in Annex I in attaining their GHG emission reduction goals, the Protocol establishes three flexibility mechanisms. The mechanisms referred to as "joint implementation" and "emissions trading" are restricted to the countries in Annex I.

Therefore, CDM is the most important mechanism in the Brazilian context, which entails the implementation in

Manuscript received December 8, 2012; revised March 1, 2013. This work was supported by FAPESP, the São Paulo Research Foundation Thematic Project and Masters Research program (Process 11/00081-5 and 2010/03512-4); and CAPES Foundation, Ministry of Education of Brazil

S. Cruz is with Department of Science and Technology Policy, State University of Campinas (Unicamp), Campinas, Brazil (e-mail: silviacruz@ige.unicamp.br).

S. Paulino is with Environmental Management, School of Arts, Sciences and Humanities, University of São Paulo, São Paulo, Brazil (e-mail: sonia.paulino@usp.br). emerging and developing countries of project activities that reduce GHG emissions, resulting in certified emission reductions (CER), popularly known as 'carbon credits', which may be purchased by countries listed in Annex I, assisting them in part fulfillment of their targets agreed upon their ratification of the Kyoto Protocol.

Based on Article 12 of the Kyoto Protocol, in addition to the purpose of GHG emission reduction, CDM projects should also promote the sustainable development in the host country of the activity.

CDM includes activities of GHG emission reduction projects established in a wide variety of sectors, including landfills. These projects have great potential for GHG reduction, since due to the bacterial decomposition of the organic waste fraction, under anaerobic conditions, methane is produced, a GHG with a global warming potential 21 times greater than carbon dioxide, therefore, with potential to generate a large amount of carbon credits.

The common practice, in Brazil and throughout the world, is to let the gas escape directly into the atmosphere through collector drains. In the Brazilian context, few landfills utilize biogas (methane) for burning or power generation, and those landfills that perform these activities are sites with CDM projects.

Out of the 431 Brazilian CDM project activities, 32 are developed on landfills, 16 of which are located in the State of São Paulo [2]. Therefore, the employment of this type of project is considered a differential between landfills, since it offers the potential to go beyond GHG reductions and contribute positively to local development.

It should be pointed out that CDM design does not merely consider global problems linked to climate change, but also focuses on the promotion of local development.

In Brazil, the aspects related to sustainable development that CDM projects must also promote, are presented in a separate document, based on Annex III of Resolution No. 1 of the Interministerial Commission on Global Climate Change (CIMGC) [3], which establishes the local co-benefits or project activity contributions for each of the five aspects relating to sustainability: 1) local environmental sustainability; 2) development of working conditions and employment generation; 3) income distribution; 4) training and technological development; and 5) regional integration and the links with other sectors.

Project approval is the responsibility of the Designated National Authority (DNA) subject to the analysis of the project in the light of the rules and regulations of the CDM Executive Board, with emphasis on the activity's sustainability aspects, as set out in Annex III of the Resolution No. 1 of the CIMGC. 
The importance of the effective participation of the civil society throughout the approval process should be noted. Therefore, another important point that the project proponents are obliged to undertake is to send invitation letters to the stakeholders, at the very least including the following actors: the City Hall involved; the city council of each municipality involved; the state environmental agency; the local environmental agency; the Brazilian Forum of NGOs and Social Movements; community associations with a direct or indirect relationship with the project activity; the state prosecutor; and the federal prosecutor.

However, reference [4] shows that only $40 \%$ of Brazilian projects clearly documented that all those stakeholders who might be affected by the project activities were invited to comment on them. Although some shortcomings may be observed with regard to the invitation letters, $86 \%$ of those projects received comments from stakeholders.

This paper addresses the issue of access or participation of the stakeholders in the implementation of CDM landfills projects.

\section{Methodology}

The landfills selected for empirical research are the Bandeirantes and São João landfills, both located in the municipality of São Paulo, in the Brazilian State of São Paulo.

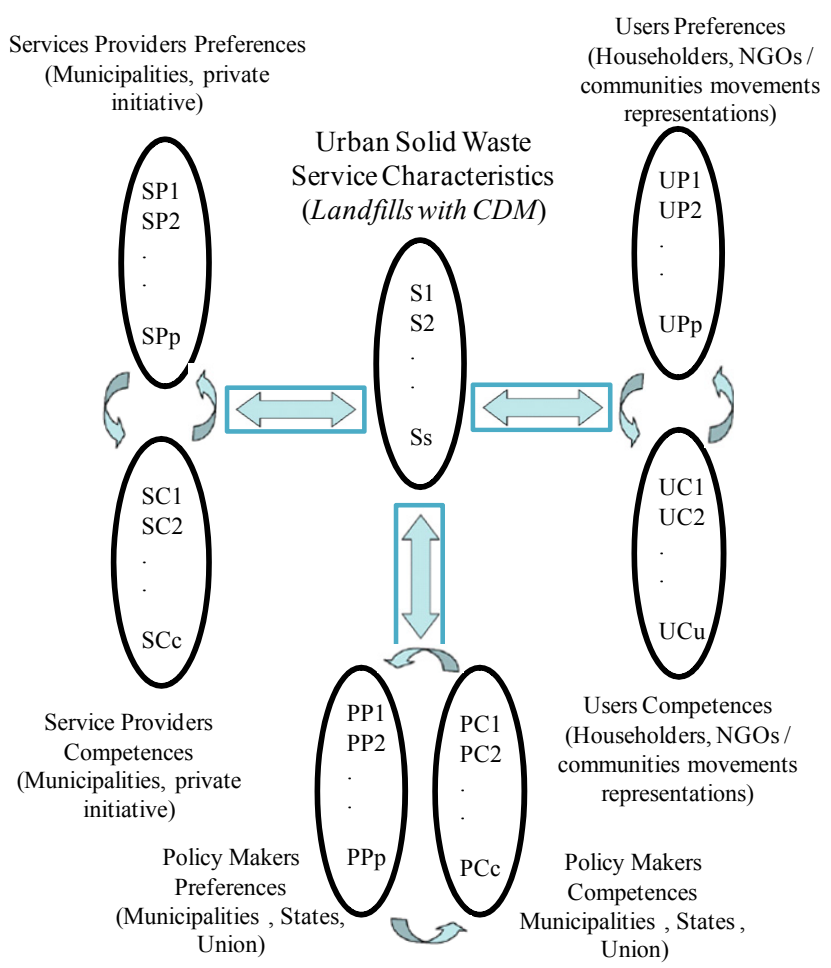

Fig. 1. Multi-agent model applied to the urban solid waste sector. Source: adapted from reference

These projects were selected for this study due to the similar characteristics of the projects, and because both are located in a city of great complexity in terms of the role of local government management.

In addition, $50 \%$ of the CER (certified emission reduction) revenues are designated to the municipal City Hall, specifically for the Environment and Sustainable Development Fund - FEMA, which is administered by the Municipal Secretariat for the Environment.

The data on the employment of the revenues from the CDM landfill projects were obtained through documentary research in the Municipal Annual Accounting Reports [5]-[7].

The data on the CDM landfill projects were obtained through documentary research in monitoring reports (MR) and project design documents (PDD), between 2003 and 2010. All these documents are available in the CDM registry of the UNFCCC, the online platform for registering CDM projects. The database of the United Nations Environment Programme (UNEPRisoe) was also consulted: this provides monthly updates on the status, generation of CER, CER purchasers, and the designated operational entity (DOE) responsible for validating CDM landfill projects.

The analysis of the stakeholders' access to CDM projects used the multi-agent model [8], adapting it to the context of CDM landfill projects, mapping the interested parties, enabling the inclusion of the political, economic and social spheres, as illustrated in Fig. 1.

The multi-agent model applied [8] for understanding the dynamics between the actors involved is largely exploited nowadays, with various analytical models developed (as the Multi-Stakeholders Platforms), focused more directly on the water resources management. Different authors raised the question of the multiplicity of actors and their interrelationships and conflicts as a way to find solutions to complex problems, as the water issue, waste management, and the natural resources scarcity, among others [9]-[11].

Through these models, is introduced the possibility of civil society involvement in decision-making and consultative processes. The new forms of institutional arrangements, as demonstrated by the multi-agent model, introduced in mutual articulation context, with the assumption that organizations are complementary and to obtain positive results, they should consolidate their potentialities.

In the participatory methods purpose, the adopted model allows the incorporation of stakeholders' perspectives, as well as emphasizes the identification of opportunities for the promotion of innovation in the public services supply, in this case, those relating to municipal solid waste sector.

The key actors or stakeholders involved with the Bandeirantes and São João CDM landfill projects were identified and data was collected through semi-structured interviews.

To enable a better understanding of the access to CDM projects, the questionnaire was organized in the following aspects: stakeholder participation, channels for recording complaints, acceptance of the projects by the population and environmental non-governmental entities, disclosure of Annex III activities to the stakeholders, cooperatives benefiting from CDM revenues, contributions of the CDM projects to environmental education programs. These aspects were presented and discussed with the stakeholders, in the second semester of 2011. 


\section{RESULTS}

First, the stakeholders are presented; and, subsequently, the aspects that characterize the stakeholders' access to the CDM projects studied.

\section{A. Identification of Agents}

The application of the multi-agent model [8], adapted to the context studied, made it possible to map the systematization of the agents identified as stakeholders involved with the Bandeirantes and São João CDM landfill projects, as demonstrated in Table I:

TABLE I: AGENTS INVOLVED WITH THE BANDEIRANTES AND SÃO JOÃO CDM LANDFILL PROJECTS

\begin{tabular}{|c|c|}
\hline Sector & Agents \\
\hline Public & $\begin{array}{c}\text { Municipal Services Secretariat; and Municipal } \\
\text { Secretariat for the Environment. }\end{array}$ \\
\hline Private & $\begin{array}{c}\text { The concessionary company responsible for the landfill } \\
\text { management; and the concessionary company } \\
\text { responsible for biogas recovery and power generation }\end{array}$ \\
\hline Users & $\begin{array}{c}\text { Representatives of associations from the communities } \\
\text { surrounding Bandeirantes and São João landfills }\end{array}$ \\
\hline
\end{tabular}

Source: Author's own

The agents identified, indicated in Table I, represent each of the areas proposed by the multi-agent model employed, namely, the public and private sectors, and users.

The analysis of the stakeholders' participation in CDM landfills projects is based on this identification.

\section{B. Access to the carbon market projects}

In brief, for the qualitative analysis of the stakeholder access to CDM projects in the Bandeirantes and São João landfills, six aspects were considered, as presented in Table II.

TABLE II: ASPECTS OF THE ANALySIS OF STAKEHOLDER ACCESS TO CDM PROJECTS

\begin{tabular}{|c|c|}
\hline Aspects & Description \\
\hline $\begin{array}{l}\text { Stakeholder } \\
\text { participation }\end{array}$ & $\begin{array}{l}\text { Identifies whether the interested parties are } \\
\text { participating in meetings / public gatherings } \\
\text { related to the CDM projects. }\end{array}$ \\
\hline $\begin{array}{l}\text { Channels for recording } \\
\text { complaints }\end{array}$ & $\begin{array}{l}\text { Initially, identifies whether formal channels } \\
\text { exist to record possible complaints and, } \\
\text { subsequent, clarification of these. }\end{array}$ \\
\hline $\begin{array}{l}\text { Acceptance of the } \\
\text { projects by the population } \\
\text { and environmental } \\
\text { non-governmental } \\
\text { entities }\end{array}$ & $\begin{array}{l}\text { Identifies whether the projects created } \\
\text { inconveniences for stakeholders. }\end{array}$ \\
\hline $\begin{array}{l}\text { Disclosure of the } \\
\text { Annex III activities to the } \\
\text { stakeholders }\end{array}$ & $\begin{array}{l}\text { Identifies if the actions contained in the } \\
\text { document Annex III are being disclosed to } \\
\text { interested parties as well as the communication } \\
\text { model employed. Since the constant access to } \\
\text { information regarding the CDM projects is a } \\
\text { key point for the effective social control of the } \\
\text { positive repercussions of these activities. }\end{array}$ \\
\hline $\begin{array}{l}\text { Cooperatives } \\
\text { benefiting from CDM } \\
\text { revenues }\end{array}$ & $\begin{array}{l}\text { Identifies if there were contributions from } \\
\text { the CDM landfill projects to the cooperatives } \\
\text { surrounding the landfills studied. }\end{array}$ \\
\hline $\begin{array}{l}\text { Contributions of CDM } \\
\text { projects to environmental } \\
\text { education programs }\end{array}$ & $\begin{array}{l}\text { Identifies if there were contributions from } \\
\text { the CDM landfill projects to environmental } \\
\text { education programs related to the subject of } \\
\text { urban solid waste management. }\end{array}$ \\
\hline
\end{tabular}

Deficiencies in access to information and to the financial results (CER revenues) of CDM projects affecting the different stakeholders should be highlighted.

Actions in this regard are limited to the holding of public meetings relating to carbon credits.

The implementation of activities geared to environmental education and inclusion of individual refuse collectors, linked to the CDM landfills projects, are restricted, to date, to potential opportunities for improvement in the services linked to the operation of landfill sites, since, in addition to increasing the lifetime of these enterprises, they also contribute to landfill gas generation, as a lower volume of inorganic material is buried in the ground.

The monitoring and management of budgetary compliance with the Fund for Environment and Sustainable Development - FEMA (the Municipal Fund of the Municipal Secretariat for the Environment that receives the CER revenues) requires the development of competencies for the financial management of these revenues, as well as the training of staff to improve the management of these different sources of revenues.

Using data from the monitoring reports, prepared by the consultancy firms responsible for the CDM projects development over the project duration, Table III shows the amounts of CER generated.

TABLE III: CER GENERATION (2007 AND 2008 AUCTIONS)

\begin{tabular}{|c|c|c|c|}
\hline \multirow[b]{2}{*}{ Auction } & \multicolumn{3}{|c|}{ Bandeirantes Landfill } \\
\hline & $\begin{array}{c}\text { CER }(\mathrm{R} \$ / \\
\text { tco } 2 \mathrm{e})\end{array}$ & $\begin{array}{c}\text { Monitoring } \\
\text { Period }\end{array}$ & CER issued \\
\hline $1 s t$ & 45 & $2004-2006$ & $1,670,306$ \\
\hline \multirow[t]{2}{*}{$2 n d$} & 50 & $\begin{array}{c}\text { Jan 2007-Mar } \\
2008\end{array}$ & 908,037 \\
\hline & & Total & $2,578,343$ \\
\hline \multicolumn{4}{|c|}{ São João landfill } \\
\hline Auction & $\begin{array}{c}\text { CER (R\$/ } \\
\text { tco } 2 \mathrm{e})\end{array}$ & $\begin{array}{l}\text { Monitoring } \\
\text { Period }\end{array}$ & CER issued \\
\hline $2 n d$ & 50 & $\begin{array}{c}\text { Jan 2007-Mar } \\
2008\end{array}$ & 527,868 \\
\hline
\end{tabular}

Source: Based on monitoring reports (MR) and project design documents (PDD); and [12].

The São Paulo Municipal Annual Accounting Reports confirm that FEMA's 2008 and 2009 revenues from the carbon credits of the Bandeirantes and São João CDM landfills projects were applied in programs and projects. However, according to data analyzed, it was found that the application of the revenues that came from sales at the Bandeirantes and São João landfills projects fell short of the values pledged, the values set aside to effect a planned payment, when compared to the updated budget $(24.21 \%$ in 2008 and $12 \%$ in 2009).

The Municipal Accounting Annual Reports show that the monitoring and the control of budgetary compliance with FEMA are precarious, mainly, due to the different sources of revenues [7]. Also there was no publication of the plan of how the revenues would be employed, which relates to the disclosure of plans, programs and projects developed with FEMA revenues. 


\section{CONCLUSION}

The residents' associations surrounding the Bandeirantes and São João landfills are effectively marginalized from these enterprises and have little influence on them: their participation is limited to public meetings to discuss the application of revenues obtained from the sale of carbon credits generated by the CDM projects studied.

The problem of asymmetrical information should be highlighted since this ultimately diminishes or prevents the effective participation of the residents' associations representing the communities congregated around the landfills. These surrounding communities are not empowered to articulate their demands effectively in the public meetings at which the discussions of experts predominate. Ultimately, this hinders the continuous flow of information and feedback which ought to enable the formation of a communications network between the actors, as long as the technical content does not constitute a factor to promote asymmetry between the various parties involved.

In this sense, the organized public meetings could be put to better use, stimulating the effective participation of the associations and the representative bodies of the surrounding communities, who would be informed in advance of the decisions to be made with regard to a CDM project developed in landfills.

There needs to be strict monitoring of the Fund for Environment and Sustainable Development (FEMA) budget compliance, as well as in the communication of the actions to be taken with the certified emission reductions revenues, given that the asymmetries encountered might put at risk the credibility and transparency of the public agents involved, in addition to the difficulties this poses for the other interested parties wishing to monitor the evolution of these projects.

\section{REFERENCES}

[1] BRASIL. (09.09.12). Kyoto Protocol to the climate change Convention, 1997. Edited and translated by the Ministry of science and technology MCT with the support of the Ministry of Foreign Affairs. [Online]. Available: http://www.mct.gov.br/clima/quioto/protocolo.htm.

[2] UNEP RISOe. (2012, December). Capacity Development for the CDM, "CDM projects in the pipeline Analysis and Database". [Online]. Available: http://www.cd4cdm.org/.

[3] Brasil, Comissão interministerial de mudanças globais do clima cimgc, Resolution n.1 of 11 September 2003, 2003

[4] J. Cole and D. Liverman, "Brazil's Clean Development Mechanism governance in the context of Brazil's historical environment-development discourses," Carbon Management, April 2011, vol. 2, no. 2, pp. 145-160, 2011.

[5] PMSP, "São Paulo Municipal Annual Accounting Reports of 2007," São Paulo City Hall, 2007.

[6] PMSP, "São Paulo Municipal Annual Accounting Reports of 2008," São Paulo City Hall, 2008.

[7] PMSP, "São Paulo Municipal Annual Accounting Reports of 2009," São Paulo City Hall, 2009.

[8] P. Windrum and M. García-Goñi, "A neo-Schumpeterian model of health services innovation," Manchester Metropolitan University Business School, Center for International Business \& Innovation, Manchester, UK, Research Policy 649-672, 2008.
[9] N. A. Steins and V. Edwards, "Platforms for collective action in multiple-use common-pool resources," Agriculture and human values, vol. 16, pp. 241-255, 1999.

[10] J. Warner, "Multi-Stakeholder Platforms: integrating society in water resource management?" in: Ambiente e Sociedade, vol. VIII/2. São Paulo: Annablume, pp. 9-28, 2005.

[11] J. Warner and A. Verhallen, "Multi-stakeholder Platforms for Integrated Catchment Management: Towards a comparative typology", paper presented in the International MSP Conference, September 2004, Wageningen, The Netherlands, 2004

[12] A. C. Delbin, "Biogás S.A. -Landfill Gas to Energy Projects," presentation held at the C40 Large Cities - Climate Summit, 2011.

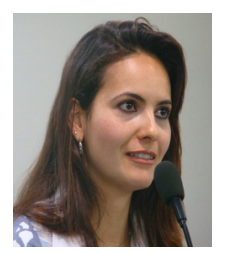

Silvia Regina Stuchi Cruz was born in São Paulo, Brazil, December 20 ${ }^{\text {th }}$, 1984. Bachelor of environmental management at School of Arts, Sciences and Humanities, University of São Paulo, São Paulo, Brazil in 2009 and Master in Scientific Policy and Technology Department of Science and Technology Policy, State University of Campinas (Unicamp), Campinas, Brazil in 2012. Currently she is PhD Student at the same University of Campinas (Unicamp), working with the main subjects: Carbon Markets; Clean Development Mechanism (CDM); and Public Service Innovation.

Her work experience includes: development of Project Design Documents (PDD) for CDM and voluntary carbon market (VCM); monitoring of validation and verification procedures; as well as using tools and methodologies for data collection and inventories generation (in accordance with the standards set by the GHG Protocol and ISO 14.064); and application of the SOCIALCARBON Standard (standard that certifies voluntary emission reduction projects for their contributions to sustainable development) in VCM projects. She participated in 2011 in the Summer School of the Research Network on Innovation, Dunkerque, France and also published an article in JIE $\left(2012 / 1-n^{\circ}\right.$ ) $)$. Currently, she is also participating in the research Project: Carbon market and opportunities for innovation in public services related to solid waste, suppoorted by São Paulo Research Foundation (FAPESP).

Ms. Cruz is a member of the group ABNT - Brazilian Technical Standards Association: Special Commission of the Voluntary Carbon Market Study (ABNT/CEE-146) that developed the technical Standard for the Voluntary Carbon Market in Brazil with the approved Standard: NBR 15948:2011 Voluntary carbon market - Principles, requirements and guidelines to commercialize verified emission reductions; and the Emission reduction projects from deforestation and forest degradation, conservation, sustainable management and increase of carbon stock (REDD + ) standard, which is under construction.

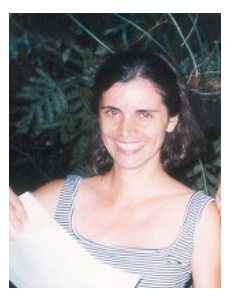

Sônia Regina Paulino was born in Sônia Regina Paulino, São Paulo, Brazil, January 14 ${ }^{\text {th }}, 1967$. Economist from São Paulo State University (UNESP), São Paulo, Brazil. Master's in Scientific Policy and Technology Department of Science and Technology Policy (DPCT), State University of Campinas (Unicamp), Campinas, Brazil. $\mathrm{PhD}$ in economics from University of Social Sciences, Toulouse, France.

She is associate professor of Environmental Management at School of Arts, Sciences and Humanities (EACH), University of São Paulo (USP), São Paulo, Brazil and accredited professor in the Postgraduate Programmes of Sustainability, at EACH-USP, and Scientific Policy and Technology Department of Science and Technology Policy, at DPCT - Unicamp, working with the main subjects: science and technology; innovation; environmental certification; market mechanisms; systems and local productive arrangements.

Besides, she did an internship in the Department of Rural Economics and Sociology, National Institute for Agronomic Research (INRA), Montpellier, France, 1997.

Prof. Paulino, is associated Researcher in the Group for Studies on the Organization of Research \& Innovation (GEOPI), Unicamp, and she is the project research coordinator of : Carbon market and opportunities for innovation in public services related to solid waste, suppoorted by São Paulo Research Foundation (FAPESP). 